\title{
Budget impact analysis on erythropoiesis- stimulating agents use for the management of chemotherapy-induced anaemia in Greece
}

\author{
Eleftheria Nikolaidi ${ }^{*}$, Magdalini Hatzikou $^{\dagger}$ and Mary Geitona ${ }^{\dagger}$
}

\begin{abstract}
Background: Chemotherapy-induced anaemia is a common and significant complication of chemotherapy treatment. Blood transfusion and administration of Erythropoiesis-Stimulating Agents (ESAs) either alone or in combination with iron are the most widely used therapeutic options. In Greece, ESAs are among the top ten therapeutic groups with the highest pharmaceutical expenditure, since they are fully reimbursed by social security funds. The objective of the study is to determine potential cost savings related with the use of biosimilar over originator ESAs for the management of the newly diagnosed chemotherapy-induced anemic patients.

Methods: A budget impact analysis has been carried through the elaboration of national epidemiological, clinical and economic data. Epidemiological data derived from WHO (GLOBOCAN) and the European Cancer Anaemia Survey. Clinical data reflect oncology patients' disease management. ESAs consumption was based on data from the biggest social security fund (IKA). The administration of ESAs under different dosing schemes and time periods has been estimated by separating them in originators and biosimilars as well as by classifying anaemic patients in responders and non-responders. Cost analysis is based on newly diagnosed patients' alternative treatment scenarios. Treatment costs and prices are used in 2012 values. The Social Security Funds's perspective was undertaken.
\end{abstract}

Results: Based on the annual incidence rates, 2.551 newly diagnosed chemotherapy-induced anemic patients are expected to be treated with ESAs. Average cost of treatment on originators ESAs for responders is $€ 2.887$ for the 15-week ESAs treatment and $€ 5.019$ for non-responders, while on biosimilars $€ 2.623$ and $€ 4.009$ respectively. Treatment cost on biosimilars is $10.1 \%$ lower than originators for responders and $25.2 \%$ for non-responders. Budget impact estimates show that treating anemic patients with originator ESAs was estimated at $€ 10.084 .800$ compared to $€ 8.460 .119$ when biosimilar ESAs were used, leading to an overall 19,20\% cost reduction favoring biosimilars.

Conclusion: In Greece, the treatment on biosimilar ESAs seems to be a cost saving option over originators for the newly diagnosed chemotherapy-induced anemic patients, since it corresponds to $5 \%$ of the annual overall consumption and expands patients' access to ESAs treatment. Health care decision making should rely on evidence based treatments in order to achieve social funds' sustainability in an era of economic recession.

Keywords: Budget impact, Biosimilars, Erythropoiesis Stimulating agents (ESAs), Greece

\footnotetext{
*Correspondence: elnikola@gmail.com

${ }^{\dagger}$ Equal contributors

School of Social Sciences, University of Peloponnese, Corinth, Greece
} 


\section{Introduction}

The European Cancer Anaemia Survey (ECAS) has revealed a high prevalence and incidence rates of anaemia in cancer patients in Europe since it examined disease's evolution, severity and management in a large and representative population sample of European cancer patients $[1,2]$. Chemotherapy-induced anaemia is a common and significant complication of chemotherapy treatment, with an incidence rate of $62.7 \%$ [1]. Additionally, anaemia has been reported in $19.5 \%$ of patients in the first chemotherapy cycle rising up to $46.7 \%$ of patients in the fourth and fifth chemotherapy cycle [1].

Therapeutic options provide supportive care through transfusion with packed red blood cells or administration of Erythropoiesis-Stimulating Agents (ESAs), with or without iron supplementation [3,4]. Transfusions are recommended to correct very low ( $<9 \mathrm{~g} / \mathrm{dl}) \mathrm{Hb}$ levels, but not for $\mathrm{Hb}$ values above that level [4-6]. Additionally, they are related with risk issues such as infections, disease transmissions and blood availability reduction [4,7-10].

Supplementing ESA therapy with intravenous iron has been shown to increase hemoglobin response rates compared with ESA alone, to levels similar to those observed for transfusions [11-13]. This evidence is also supported by Aapro et al., 2012 [14] review which showed higher efficacy of intravenous iron over oral or no iron in reducing blood transfusions, increasing haemoglobin levels, and improving quality of life in ESAs-treated anaemic cancer patients. Additionally, by adding intravenous iron to ESA therapy the cost of ESA treatment across the therapeutic class is reduced [15].

ESAs are genetically engineered forms of erythropoietin. Based on their approved indications, by the European Medicines Agency (EMA), they are used for the treatment of symptomatic anaemia associated with chronic renal failure as well as the treatment of adult cancer symptomatic anaemia patients with non-myeloid malignancies receiving chemotherapy. It should be mentioned that there is a controversy in the international literature concerning safety and effectiveness issues related with the use of ESAs [16,17].

There is suggestive evidence that the use of ESAs in patients with chemotherapy-induced anaemia may improve disease-specific measures of quality of life and decreases the use of blood transfusions [18-25].

The first biosimilars of ESAs were developed after the patent expiry of the originators. The term biosimilar designates a second-entry version of biological medicinal products whose complex molecular structure is more challenging and requires greater resources than traditional generics [26-31]. The approval process that has been applied for generics is unsuitable for biosimilars and specific provisions for these products were developed. Their authorization is granted on the basis of quality, safety and efficacy data [32]. There is a real choice available to physicians when selecting different ESAs products, since it appears to have no significant difference in the effectiveness and safety of different agents in managing chemotherapy-induced anaemia [5,33].

ESAs are among the top ten therapeutic groups with the highest pharmaceutical expenditure ranging from $26,4 \%$ in 2008 to $22,7 \%$ in 2010 , as reported by IKA, the biggest social security fund in Greece until 2011 [34]. The market share (MS) of originator epoetins was 99\% in 2008 corresponding to $€ 41,4$ million. In 2009 ESAs expenditure reached $€ 43$ million, with $94 \%$ and $6 \%$ MS for original and biosimilar ESAs respectively, whilst in 2010 an inverse tendency appeared presenting an increase of MS of biosimilars to $19 \%$. The same year ESAs expenditure was almost halved ( $€ 19$ million) since costcontainment measures were implemented such as flat price cuts and stricter control of prescriptions [35]. Therefore, although ESAs are widely used treatments, they remain a costly option since they are fully reimbursed (100\%) by all social security funds without any patient co-payment. Under the current economic recession that Greece is facing, numerous cost containment measures have been implemented in all fiscal sectors. In the health care sector, the majority of the measures performed targeted to pharmaceutical expenditure [35].

The objective of this paper is to elaborate epidemiological, clinical and economic data on ESAs consumption in Greece, in order to determine potential cost savings by using biosimilar over originator ESAs under different dosing schemes for the management of the newly diagnosed chemotherapy-induced anemic patients.

\section{Methods}

A budget impact analysis has been carried out based on national epidemiological, clinical and economic data. Epidemiological data concerning the incidence of cancer in Greece derived from IARC-WHO (GLOBOCAN) 2008 [36]. Anaemia treatments separated in ESAs (either alone or in combination with iron and/or transfusion), transfusion (alone or with iron) and iron alone were based on the European Cancer Anaemia Survey (ECAS) [1]. Incidence of cancer-associated anaemia for the Greek oncologic patients was performed by type of cancer: breast, lung, GI/colocteral, head/neck, gynecological, lymphoma/myeloma, leukemia, urogenital and a category containing the remaining cancer types.

The classification of ESAs per $\mathrm{Hb}$ level and strength has been estimated by separating them in originators (darbepoetin $\alpha$, epoetin $\alpha$ and epoetin $\beta$ ) and biosimilars (epoetin $\alpha$ and epoetin $\zeta$ ) for a two month period as well as for a time period of six chemotherapy cycles on ESA treatment, aligned with routine chemotherapy duration. Approved ESAs classification, per strength and price 
among originators and biosimilars marketed in Greece is presented in Table 1.

The recommended initial doses of ESAs, based on their approved by EMA Summary of Product Characteristics (SPC) are $30.000 \mathrm{IU} /$ week (or $3 \times 10.000 \mathrm{IU} /$ week) for epoetin $\alpha$, epoetin $\beta$ and epoetin $\zeta$ and $150 \mathrm{mcg} /$ week for darbepoetin $\alpha$. Alternate approved doses for epoetin $\alpha /$ epoetin $\zeta$ and darbepoetin $\alpha$ are 40.000 IU/week and $500 \mathrm{~m} \mathrm{cg} / 3$ weeks respectively.

If $\mathrm{Hb}$ has not increased by at least $1 \mathrm{~g} / \mathrm{dl}$ after 4-week treatment with epoetin $\alpha$, epoetin $\beta$ and epoetin $\zeta$, the dose may be escalated to $200 \%$ of the initial dose. Based on the US National Comprehensive Cancer Network, $(\mathrm{NCCN})$ clinical practice guidelines in Oncology for the treatment of cancer and chemotherapy-induced anaemia [37], the dose of darbepoetin $\alpha$ could be increased up to $4.5 \mu \mathrm{g} / \mathrm{kg}$ once a week corresponding to $300 \mu \mathrm{cg} /$ week in case of no response at 6-week treatment with the initial darbepoetin dose. In order to be able to compare darbepoetin with the rest epoetins, at various stages of

Table 1 ESAs classification per strength (IU/mcg) and price between originator \& biosimilar products in 2012

\begin{tabular}{|c|c|c|c|}
\hline \multicolumn{4}{|c|}{ Originators } \\
\hline Brand & Strength & $\begin{array}{c}\text { Active } \\
\text { substance }\end{array}$ & $\begin{array}{l}\text { Average hospital } \\
\text { price/syringe }(€)^{*}\end{array}$ \\
\hline \multirow{5}{*}{ ARANESP } & 150 MCG & & 192.27 \\
\hline & 300 MCG & Darbepoetin a & 385.11 \\
\hline & $500 \mathrm{MCG}$ & & 635.49 \\
\hline & $10.000 \mathrm{IU}$ & & 60.79 \\
\hline & $20.000 \mathrm{IU}$ & Epoetin $\beta$ & 149.68 \\
\hline \multirow{2}{*}{ NEO RECORMON } & $30.000 \mathrm{IU}$ & & 190.16 \\
\hline & $60.000 \mathrm{IU}$ & & 342.25 \\
\hline & $10.000 \mathrm{IU}$ & & 53.9 \\
\hline & $20.000 \mathrm{IU}$ & Epoetin a & 122.79 \\
\hline \multirow[t]{2}{*}{ EPREX } & $30.000 \mathrm{IU}$ & & 196.55 \\
\hline & $40.000 \mathrm{IU}$ & & 212.42 \\
\hline \multicolumn{4}{|c|}{ Biosimilars } \\
\hline Brand & Strength & Active substance & $\begin{array}{l}\text { Average hospital } \\
\text { price/syringe }(€)^{*}\end{array}$ \\
\hline \multirow[t]{5}{*}{ ABSEAMED } & $10.000 \mathrm{IU}$ & & 50.26 \\
\hline & $20.000 \mathrm{IU}$ & Epoetin a & 101.91 \\
\hline & $30.000 \mathrm{IU}$ & & 152.87 \\
\hline & $40.000 \mathrm{IU}$ & & 203.83 \\
\hline & $10.000 \mathrm{IU}$ & & 47.41 \\
\hline \multirow[t]{4}{*}{ BINOCRIT } & $20.000 \mathrm{IU}$ & Epoetin a & 94.37 \\
\hline & $30.000 \mathrm{IU}$ & & 141.55 \\
\hline & $40.000 \mathrm{IU}$ & & 188.73 \\
\hline & $10.000 \mathrm{IU}$ & Epoetin $\zeta$ & 54.51 \\
\hline RETACRIT & $40.000 \mathrm{IU}$ & & 255.54 \\
\hline
\end{tabular}

*Hospital Prices 2012. the chemotherapy-induced anaemia treatment, the escalation of dosage scheme to $200 \%$ was performed in 4 weeks interval instead of 6 weeks (Table 2).

In case the $\mathrm{Hb}$ has not increased by at least $1 \mathrm{~g} / \mathrm{dl}$ after 4 consecutive weeks ( 8 weeks in total) with the escalated ESAs dose, the treatment with epoetin $\alpha$, epoetin $\beta$ and epoetin $\zeta$ should be discontinued. Concerning darbepoetin $\alpha$, in case of patient's non-response (fatigue, haemoglobin response) after nine weeks of treatment, further therapy may not be effective, according to the SPC recommendations.

Based on the national clinical guidelines [38] as well as the European Society for Medical Oncology (ESMO) guidelines [39], chemotherapy duration varies from 4-6 cycles depending on the type of cancer. In the current analysis six cycles of chemotherapy were used at three-week intervals. A chemotherapy cycle was defined as the three-week period with the chemotherapy being administered at the first week of each cycle. The 6-cycle chemotherapy corresponds to 18 weeks. The initiation of ESAs treatment was assumed to take place at the beginning of the second chemotherapy cycle i.e. at week 4 and continued until the end of the 6th cycle of chemotherapy (end of week 18), for a total of 15 weeks $[1,5]$.

Two different ESAs escalating dosing schemes were used (Table 2) leading to the classification of chemotherapy-induced anaemic patients in responders and non-responders with a $50 \%$ response rate per group. Responders were administered the recommended initial doses of ESAs for the total of 15 weeks, while non responders' dosing scheme was escalated to $200 \%$ of the initial dose in the beginning of the week 9 until the end of 15 th week.

Each ESA can be used in more than one fixed dosing scenario (Table 2). In order to enable a clinically relevant comparison, the cost of all possible fixed dosing schemes were taken into account and average cost estimates per month of originator and biosimilar ESAs were used.

Cost analysis among originator and biosimilar ESAs was based on a two-month treatment period per patient. In the budget impact analysis the cost estimates for the two-month period treatment were extrapolated to a sixcycle chemotherapy framework based on the incidence rates, $\mathrm{Hb}$ level, distributed in responders and non responders. Hospital prices were averaged using 2012 values. The Social Security Funds's perspective was undertaken and for data elaboration Microsoft Excel version 7 was used.

\section{Results}

Newly diagnosed cancer patients in Greece are estimated at 37.089 out of which 14.660 are expected to be treated for anaemia (Table 3). From those 2.551 (17.4\%) chemotherapyinduced anaemic patients will be treated with ESAs. 
Table 2 Dosage Scheme of ESAs for "Responders" and "Non-Responders" Anaemic Patients for a two-month period

\begin{tabular}{|c|c|c|c|c|}
\hline \multirow{2}{*}{$\begin{array}{c}\text { Active } \\
\text { substance }\end{array}$} & \multicolumn{2}{|c|}{ Responders (Hb increase $\geq 1 \mathrm{~g} / \mathrm{dl}$ ) } & \multicolumn{2}{|c|}{ Non responders ( $\mathrm{Hb}$ increase $<1 \mathrm{~g} / \mathrm{dl}$ ) } \\
\hline & First month treatment & Second month treatment & First month treatment & Second month treatment \\
\hline Darbepoetin a & $\begin{array}{l}150 \mathrm{MCG} / \text { week or } \\
500 \mathrm{MCG} / 3 \text { weeks }\end{array}$ & $\begin{array}{l}150 \mathrm{MCG} / \text { week or } \\
500 \mathrm{MCG} / 3 \text { weeks }\end{array}$ & $\begin{array}{l}150 \text { MCG/week or } \\
500 \text { MCG/3 weeks }\end{array}$ & 300 MCG/week \\
\hline Epoetin $\beta$ & $\begin{array}{l}3 \times 10.000 \mathrm{IU} / \text { week } \\
\text { or } 30.000 \mathrm{IU} / \text { week }\end{array}$ & $\begin{array}{c}3 \times 10.000 \mathrm{IU} / \text { week or } \\
30.000 \mathrm{IU} / \text { week }\end{array}$ & $\begin{array}{c}3 \times 10.000 \mathrm{IU} / \text { week or } \\
30.000 \mathrm{IU} / \text { week }\end{array}$ & $\begin{array}{c}3 \times 20.000 \mathrm{IU} / \text { week or } \\
2 \times 30.000 \mathrm{IU} / \text { week or } \\
1 \times 60.000 \mathrm{IU} / \text { week }\end{array}$ \\
\hline Epoetin a & $\begin{array}{c}3 \times 10.000 \mathrm{IU} / \text { week or } \\
40.000 \mathrm{IU} / \text { week or } \\
30.000 \mathrm{IU} / \text { week }\end{array}$ & $\begin{array}{c}3 \times 10.000 \mathrm{IU} / \text { week or } \\
40.000 \mathrm{IU} / \text { week or } \\
30.000 \mathrm{IU} / \text { week }\end{array}$ & $\begin{array}{c}3 \times 10.000 \mathrm{IU} / \text { week or } \\
40.000 \mathrm{IU} / \text { week or } \\
30.000 \mathrm{IU} / \text { week }\end{array}$ & $\begin{array}{c}3 \times 20.000 \mathrm{IU} / \text { week or } \\
2 \times 30.000 \mathrm{IU} / \text { week }\end{array}$ \\
\hline Epoetin $\zeta$ & $\begin{array}{l}3 \times 10.000 \mathrm{IU} / \text { week } \\
\text { or } 40.000 \mathrm{IU} / \text { week }\end{array}$ & $\begin{array}{c}3 \times 10.000 \mathrm{IU} / \text { week or } \\
40.000 \mathrm{IU} / \text { week }\end{array}$ & $\begin{array}{c}3 \times 10.000 \mathrm{IU} / \text { week or } \\
40.000 \mathrm{IU} / \text { week }\end{array}$ & $6 \times 10.000 \mathrm{IU} /$ week \\
\hline
\end{tabular}

Transfusion alone or with iron, was the second most frequent choice of physicians administered to 2.184 patients (14.9\%) and iron alone was the last one administered to 953 patients $(6.5 \%)$.

The cost of ESAs treatment classified per $\mathrm{Hb}$ level, responders and non responders on originators and biosimilar, is presented in Table 4. The cost difference for responders on originators versus biosimilars is $€ 336.511$ and for non-responders is $€ 1.288 .170$ respectively. The savings associated with the use of biosimilars for both patients categories (responders and nonresponders) is estimated at $€ 1.624 .681$.

Average cost per patient for responders is $€ 2.887$, using originators (darbepoetin $\alpha$, epoetin $\alpha$ and epoetin $\beta)$ for the 15-week ESAs treatment (6-cycles chemotherapy) and $€ 5.019$ in the case of non-responders. Average cost of patients on biosimilar treatment (epoetin $\alpha$ and epoetin $\zeta)$ is $€ 2.623$ for responders and $€ 4.009$ for non- responders. Responder patients on biosimilars were estimated to have $10.1 \%$ lower cost than patients on original ESAs. In case of non-responders, the cost difference between originators and biosimilars is even higher reaching approximately $25.2 \%$ favoring also biosimilars.

\section{Discussion}

Budget impact estimates reveal that treating newly diagnosed chemotherapy-induced anemic patients with originator ESAs for 6 cycles chemotherapy was estimated at $€ 10.084 .800$ compared to $€ 8.460 .119$ when biosimilar ESAs were used in both responder and non-responder patient categories, leading to an overall $19,20 \%$ cost reduction favoring biosimilars. Consequently, budget impact analysis showed that the administration of biosimilar ESAs seems to be a cost saving option over originators, since the savings from the use of biosimilars approximates $5 \%(€ 1,5$ million $)$ of the total annual ESAs consumption in

Table 3 Incidence of patients with cancer associated anaemia in Greece and categorization per type of anaemia treatment

\begin{tabular}{|c|c|c|c|c|c|c|c|}
\hline Type of cancer & $\begin{array}{l}\% \text { Of patients } \\
\text { with cancer } \\
\text { associated } \\
\text { anaemia on } \\
\text { treatment }^{1}\end{array}$ & $\begin{array}{l}\text { Newly } \\
\text { diagnosed } \\
\text { cancer } \\
\text { patients in } \\
\text { Greece }\end{array}$ & $\begin{array}{l}\text { Number of Greek } \\
\text { patients with } \\
\text { cancer associated } \\
\text { anaemia or } \\
\text { treatment }^{1,2}\end{array}$ & $\begin{array}{c}\text { Number of } \\
\text { Greek patients } \\
\text { on treatment } \\
\text { with ESAs } \\
(17,4 \%)^{1,2}\end{array}$ & $\begin{array}{l}\text { Number of Greek } \\
\text { patients on } \\
\text { treatment with } \\
\text { transfusion } \\
(14,9 \%)^{1,2}\end{array}$ & $\begin{array}{c}\text { Number of } \\
\text { Greek patients } \\
\text { on treatment } \\
\text { with iron only } \\
(6,5 \%)^{1,2}\end{array}$ & $\begin{array}{c}\text { Number of } \\
\text { Greek patients } \\
\text { under no } \\
\text { treatment } \\
(61,2 \%)^{1,2}\end{array}$ \\
\hline Breast & 26.2 & 4.349 & 1.139 & 198 & 170 & 74 & 697 \\
\hline Lung & 47.7 & 6.667 & 3.180 & 553 & 474 & 207 & 1.946 \\
\hline Gl-Colon & 33 & 5.062 & 1.670 & 291 & 249 & 109 & 1.022 \\
\hline Head \& Neck & 46.1 & 1.100 & 507 & 88 & 76 & 33 & 310 \\
\hline Gynaecological & 42.7 & 2.026 & 865 & 151 & 129 & 56 & 529 \\
\hline Lymphoma/myeloma & 47.4 & 1.388 & 658 & 114 & 98 & 43 & 403 \\
\hline Leukaemia & 53.3 & 1.512 & 806 & 140 & 120 & 52 & 493 \\
\hline Urogenital & 43 & 5.610 & 2.412 & 420 & 359 & 157 & 1.476 \\
\hline Other & 36.5 & 9.375 & 3.422 & 595 & 510 & 222 & 2.094 \\
\hline Total & 375.9 & 37.089 & 14.660 & 2.551 & 2.184 & 953 & 8.972 \\
\hline
\end{tabular}

Sources: ${ }^{1}$ (Ludwig et al. 2004), ${ }^{2}$ WHO-Globocan 2008. 
Table 4 Cost of 15-week ESAs treatment (6-cycles chemotherapy) for responder \& non responder patients receiving originators or biosimilars per Hb level

\begin{tabular}{|c|c|c|c|c|c|c|c|c|c|}
\hline $\begin{array}{c}\text { HB } \\
\text { Nadir (g/dl) }\end{array}$ & $\begin{array}{c}\% \text { of } \\
\text { patients per } \\
\text { Hb level }\end{array}$ & $\begin{array}{l}\text { Number of } \\
\text { Greek patients } \\
\text { treated with } \\
\text { ESAs per } \\
\text { Hb Level }\end{array}$ & $\begin{array}{l}\text { Responders } \\
\text { Cost of } 15 \text { weeks } \\
\text { treatment with } \\
\text { originator ESAs }(€)\end{array}$ & $\begin{array}{c}\text { Non } \\
\text { responders } \\
\text { Cost of } 15 \text { weeks } \\
\text { treatment with } \\
\text { originator ESAs }(€)\end{array}$ & $\begin{array}{l}\text { Cost of } 15 \text { weeks } \\
\text { treatment with } \\
\text { Biosimilar ESAs }(€)\end{array}$ & $\begin{array}{c}\text { Non } \\
\text { responders } \\
\text { Cost of } 15 \text { weeks } \\
\text { treatment with } \\
\text { Biosimilar ESAs }(€)\end{array}$ & $\begin{array}{c}\text { Cost } \\
\text { difference } \\
\text { for responders } \\
\text { originators vs. } \\
\text { Biosimilars }(€)\end{array}$ & $\begin{array}{c}\text { Cost } \\
\text { difference for } \\
\text { non responders } \\
\text { originators vs. } \\
\text { Biosimilars }(€)\end{array}$ & $\begin{array}{c}\text { Total } \\
\text { difference } \\
\text { originators vs } \\
\text { Biosimilars }(€\end{array}$ \\
\hline$<9$ & 33.5 & 855 & 1.233 .547 & 2.144 .861 & 1.120 .816 & 1.713 .324 & 112.731 & 431.537 & 544.268 \\
\hline $9.0-9.9$ & 27.5 & 701 & 1.012 .613 & 1.760 .707 & 920.072 & 1.406 .460 & 92.541 & 354.247 & 446.787 \\
\hline 10.0-10.9 & 24.7 & 630 & 909.511 & 1.581 .435 & 826.392 & 1.263 .257 & 83.118 & 318.178 & 401.296 \\
\hline $11.0-11.9$ & 9.5 & 242 & 349.812 & 608.244 & 317.843 & 485.868 & 31.969 & 122.376 & 154.345 \\
\hline$>12.0$ & 4.8 & 122 & 176.747 & 307.323 & 160.594 & 245.491 & 16.153 & 61.832 & 77.985 \\
\hline Total & 100 & 2.551 & 3.682.229 & 6.402 .570 & 3.345 .718 & 5.114 .400 & 336.511 & 1.288 .170 & 1.624 .681 \\
\hline
\end{tabular}


the country. It should be noted that the above mentioned savings correspond to the additional treatment of 490 anaemic patients.

However, there are certain limitations in the current analysis that should be discussed. First, given the limited experience in the use of biosimilars, it is rather difficult to compare and generalize our findings with international literature. The only study with comparable results is that of Aapro et al. [5] which compared the cost of chemotherapy-induced anaemia among originator epoetin $\alpha$, epoetin $\beta$ and darbepoetin $\alpha$ and biosimilar epoetin $\alpha$ at the level of a single patient using various dosing scenarios. Although the above study compared a single biosimilar agent with the rest originators category whilst in our analysis all biosimilar treatments were used and compared with the whole originators category, still both studies revealed saving by the use of biosimilars. Second, given that substitution on ESAs is not recommended by the European Agencies for medicines, the current research hypothesis is conservative, since it is based only on incidence rates without taking into consideration cancer patients already on treatment with an originator ESA. Additionally, the rates of cancer anaemic patients on treatment were based on ECAS study performed in 2004, which might not reflect potential changes in the current epidemiological rates. Also the assumption of $50 \%$ response rate of the cancer anaemia patients was necessary due to lack of respective international data in order to keep a balance between the comparable categories. Finally, the fact that the present study focuses on the ESAs consumption and does not take into consideration neither the alternative treatment option of transfusions nor the supplementary treatment of ESAs with iron constitutes another limitation.

It is believed that although sound national and international evidence have been used for the estimation of epidemiological chemotherapy-induced anaemia and disease management data, still further research on patient reported outcomes deriving from empirical evidence, is needed. In addition, the authors would like to point out that an evaluation of the efficacy/effectiveness and safety of ESAs for their intended use and their approved therapeutic indications were not within the aims of the study. The current budget-impact analysis was based on the use of ESAs in Greece, their approved therapeutic indications and posology regimens, among originators and biosimilars.

Despite the above research limitations, it should be mentioned that the conduction of budget impact analysis of originators versus biosimilars seems to be important both at the micro and macro-economic level, especially for reimbursement decisions making and health resources re-allocation purposes. However, comparing among alternative therapeutic options for managing chemotherapy- induced anaemia, more complex analysis is needed. The conduction of cost-effectiveness or cost-utility analyses focusing on alternative management strategies for chemotherapy-induced anaemia might result in more comparable treatment costs and clinical outcomes. Economic evaluation studies combine budgets' savings with clinical evidence that could lead in the expansion of patients' access to ESAs, the avoidance of blood wastes as well as to the improvement of patients' quality of life.

\section{Conclusion}

The administration of biosimilar ESAs to newly diagnosed chemotherapy-induced anemic patients seems to be a cost saving option over originators, although further research on patient reported outcomes and empirical evidence is needed. Under the economic recession that Greece is experiencing, health care decision making should rely on evidence based treatments in order to achieve social funds' sustainability.

\section{Abbreviations}

ESAs: Erythropoiesis-Stimulating Agents; Hb: Heamoglobin; ECAS: European Cancer Anaemia Survey; EMA: European Medicines Agency; MS: Market Share; IKA: Social Security Fund; SPC: Summary of Product Characteristics; NCCN: US National Comprehensive Cancer Network; ESMO: European Society for Medical Oncology.

\section{Competing interests}

The authors declare that they have no competing interests.

\section{Authors' contributions}

All authors have equally contributed to the writing of the manuscript and MG critically reviewed, corrected and approved the final version.

\section{Authors' information}

MG is Associate Professor of Health Economics at University of Peloponnese. $\mathrm{MH}$ is research associate at University of Peloponnese and holds the position of Health Economics Manager at Novartis Hellas. EN is postgraduate student at University of Peloponnese and employee of National Organization for Medicines in Greece.

Received: 7 December 2012 Accepted: 12 July 2013

Published: 16 July 2013

\section{References}

1. Ludwig H, Van Belle S, Barrett-Lee P, Birgegard G, Bokemeyer C, Gasco P, Kosmidis P, Krzakowski M, Nortier J, Olmi P, Schneider M, Schrijvers D: The European Cancer Anaemia Survey (ECAS): A large, multinational, prospective survey defining the prevalence, incidence, and treatment of anaemia in cancer patients. Eur J Cancer 2004, 40:2293-2306.

2. Parkin DM, Bray F, Ferlay J, Pisani P: Estimating the world cancer burden: Globocan 2000. Int J Cancer 2001, 94:153-156.

3. Rodgers GM, Becker PS, Blinder M, Cella D, Chanan-Khan A, Cleeland C, Coccia PF, Djulbegovic B, Gilreath JA, Kraut EH, Matulonis UA, Millenson MM, Reinke D, Rosenthal J, Schwartz RN, Soff G, Stein RS, Vlahovic G, Weir AB: Cancer-and Chemotherapy-Induced Anaemia. J Natl Compr Canc Netw 2012, 10:628-653.

4. Aapro M, Link H: Update on EORTC guidelines and anaemia management with erythropoiesis-stimulating agents. Oncologist 2008, 13(Suppl. 3):33-36.

5. Aapro $M$, Cornes $P$, Sun $D$, Abraham I: Comparative cost efficiency across the European $\mathrm{G} 5$ countries of originators and a biosimilar erythropoiesis stimulating agent to manage chemotherapy - induced anaemia in patients with cancer. Therapeutic Advances Med Oncol 2012, 0(0):1-11. 
6. Bokemeyer C, Aapro MS, Courdi A, Foubert J, Link H, Osterborg A, Repetto L, Soubeyran P: EORTC guidelines for the use of erythropoietic proteins in anaemic patients with cancer: 2006 update. Eur J Cancer 2007, 43:258-270

7. Society of Thoracic Surgeons Blood Conservation Guideline Task Force: Perioperative Blood Transfusion and Blood Conservation in Cardiac Surgery: The Society of Thoracic Surgeons and The Society of Cardiovascular Anesthesiologists Clinical Practice Guideline. Ann Thorac Surg 2007, 83:S27-S86.

8. Repetto L, Moeremans K, Annemans L: European guidelines for the management of chemotherapy-induced anaemia and health economic aspects of treatment. Cancer Treat Rev 2006, 32(Suppl 2):S5-S9.

9. Aapro MS, Birgegård G, Bokemeyer C, Cornes P, Foubert J, Gascon P, Glaspy J, Hellström-Lindberg E, Link H, Ludwig H, Osterborg A, Repetto L, Soubeyran P: Erythropoietins should be used according to guidelines. Lancet Oncol 2008, 9(5):412-413.

10. Upile T, Jeries W, Sandison A, Singh S, Rhys-Evans P, Sudhoff H, Hopper C: The direct effects of stored blood products may worsen prognosis of cancer patients; shall we transfuse or not? An explanation of the adverse oncological consequences of blood product transfusion with a testable hypothesis driven experimental research protocol. Med Hypotheses 2008, 71:498-492.

11. Auerbach $M$, Ballard $H$, Trout JR, Mcllwain M, Ackerman A, Bahrain H, Balan S, Barker L, Rana J: Intravenous iron optimizes the response to recombinant human erythropoietin in cancer patients with chemotherapy-related anaemia: a multicenter, open label, randomized trial. J Clin Oncol 2004, 22:1301-1307.

12. Auerbach M, Silberstein PT, Webb RT, Averyanove A, Ciuleanu TE, Shao J, Bridges K: Darbepoetin alfa 300 or $500 \mu g$ once every 3 weeks with or without intravenous iron in patients with chemotherapy induced anaemia. Am J Hematol 2010, 85:655-663.

13. Bastit L, Vandebroek A, Altintas S, Gaede B, Pinter T, Suto TS, Mossman TW, Smith KE, Vansteenkiste JF: Randomized, multicenter, controlled trial comparing the efficacy and safety of darbepoetin alpha administered every three weeks with or without intravenous iron in patients with chemotherapy-induced anaemia. J Clin Oncol 2008, 26:1611-1618.

14. Aapro M, Österborg A, Gascón P, Ludwig H, Beguin Y: Prevalence and management of cancer-related anaemia, iron deficiency and the specific role of i.v. iron. Ann Oncol 2012, 23:1954-1962.

15. Szucs TD, Blank PR, Schwenkglenks M, Aapro M: Potential health economic impact of intravenous iron supplementation to erythropoiesisstimulating agent treatment in patients with cancer or chemotherapy induced anaemia. Oncology 2011, 81:45-49.

16. Bohlius J, Schmidlin K, Brillant C, Schwarzer G, Trelle S, Seidenfeld J, Zwahlen M, Clarke M, Weingart O, Kluge S, Piper M, Rades D, Steensma D, Djulbegovic B, Fey M, Ray-Coquard I, Machtay M, Moebus V, Thomas G, Untch M, Schumacher M, Egger $M$, Engert A: Recombinant human erythropoiesis-stimulating agents and mortality in patients with cancer: a meta-analysis of randomised trials. Lancet 2009, 373:1532-1542.

17. Bohlius J, Schmidlin K, Brillant C, Schwarzer G, Trelle S, Seidenfeld J, Zwahlen M, Clarke MJ, Weingart O, Kluge S, Piper M, Napoli M, Rades D, Steensma D, Julbegovic B, Fey MF, Ray-Coquard I, Moebus V, Thomas G, Untch M, Schumacher M, Egger M, Engert: A Erythropoietin or Darbepoetin for patients with cancer--meta-analysis based on individual patient data. Cochrane Database Syst Rev 2010, 11:CD007303.

18. Cella D: The effects of anaemia and anaemia treatment on the quality of life of people with cancer. Oncology (Williston Park) 2002, 16(suppl 10):125-132.

19. Cella D, Kallich J, McDermott A, Xu X: The longitudinal relationship of hemoglobin, fatigue and quality of life in anaemic cancer patients: Results from five randomized clinical trials. Ann Oncol 2004, 15:979-986.

20. Tonelli M, Hemmelgarn B, Reiman T, Manns B, Reaume MN, Lloyd A, Wiebe N, Klarenbach S: Benefits and harms of erythropoiesis-stimulating agents for anaemia related to cancer: a meta-analysis. CMAJ 2009, 180(11):E62-E71.

21. Kanavos P, Yfantopoulos J, Vandoros C, Politis C: The economics of blood: gift of life or a commodity?. Int J Technol Assess Health Care 2006, 22(3):338-43.

22. Pronzato P, Cortesi E, Ritjt C, Bois A, Moreno-Nogueira J, Freire de Oliveira C, Barrett-Lee P, Ostler PJ, Rosso R: Epoetin Alfa Improves Anaemia and Anaemia-Related, Patient-Reported Outcomes in Patients with Breast Cancer Receiving Myelotoxic Chemotherapy: Results of a European, Multicenter, Randomized, Controlled Trial. Oncologist 2010, 15:935-943.

23. Littlewood TJ, Bajetta E, Nortier JW, Vercammen E, Rapoport B: Effects of epoetin alfa on hematologic parameters and quality of life in cancer patients receiving nonplatinum chemotherapy: Results of a randomized, double-blind, placebo controlled trial. J Clin Oncol 2001, 19:2865-2874.

24. Witzig TE, Silberstein PT, Loprinzi CL, Sloan JA, Novotny PJ, Mailliard JA, Rowland KM, Alberts SR, Krook JE, Levit R, Morton RF: Phase III, randomized, double- blind study of epoetin alfa compared with placebo in anaemic patients receiving chemotherapy. J Clin Oncol 2005, 23:2606-2617.

25. Tonia T, Mettler A, Robert N, et al: Erythropoietin or darbepoetin for patients with cancer. Cochrane Database Syst Rev 2012, 12:CD003407.

26. Duh MS, Weiner JR, White LA, Lefebvre P, Greenberg PE: Management of anaemia: a critical and systematic review of the cost effectiveness of erythropoiesis-stimulating agents. PharmacoEconomics 2008, 26(2):99-120.

27. Schellekens H: Biosimilar epoetins: how similar are they? Eur J Hosp Pharm 2004, 3:43-7.

28. Rovira J, Espin J, Garcia L, De Labry A: The impact of biosimilars' entry in the EU market. Andalusian Sch Pub Health 2011, 30:1-83.

29. Chow SC, Endrenyi L, Lachenbruch PA, Yang LY, Chi E: Scientific factors for assessing biosimilarity and drug interchangeability of follow-on biologics. Biosimilars 2011, 1:13-26. http://www.dovepress.com.

30. Karalis $V$, Symillides M, Macheras P: Novel methods to assess bioequivalence. Expert Opin Drug Metab Toxicol 2011, 7(1):79-88.

31. Bhupinder SS, Vikrant S: Biosimilars: an overview. Biosimilars 2011, 1:1-11. http://www.dovepress.com.

32. EMEA: uideline on non-clinical and clinical development of similar biological medicinal products containing recombinant erythropoietins (Revision) EMEA CHMP/BMWP/301636/2008 Corr.*. London, United Kingdom: The European Medicines Agency Evaluation of Medicines for Human Use; 2010.

33. Schrijvers D, De Samblanx H, Roila F, ESMO Guidelines Working Group: Erythropoiesis-stimulating agents in the treatment of anaemia in cancer patients: ESMO Clinical Practice Guidelines for use. Ann Oncol 2010, 21 (Supplement 5):244-247.

34. Kani C, Litsa P, Alexopoulou Hatzikou M, Delibasi S, Geitona M: Striving for Affordable treatments within the Greek environment: Do epoetin biosimilars help? Value Health 2011, 14:412-413.

35. Geitona M: Assessing the value of medicinal innovation in an era of increasing austerity. Soc Cohesion Dev 2012, 7(1):39-51.

36. International Agency for Research on Cancer - World Health Organization, (IARC-WHO), Globocan; 2008. http://globocan.iarc.fr.

37. US National Comprehensive Cancer Network, NCCN: Clinical Practice Guidelines in Oncology, Cancer- and Chemotherapy-Induced Anaemia. http:// www.nccn.org/index.asp.

38. National Organization for Medicines, EOF. http://www.eof.gr.

39. European Society for Medical Oncology (ESMO). http://www.esmo.org

doi:10.1186/1478-7547-11-16

Cite this article as: Nikolaidi et al: Budget impact analysis on erythropoiesis-stimulating agents use for the management of chemotherapy-induced anaemia in Greece. Cost Effectiveness and Resource Allocation 2013 11:16.

\section{Submit your next manuscript to BioMed Central and take full advantage of:}

- Convenient online submission

- Thorough peer review

- No space constraints or color figure charges

- Immediate publication on acceptance

- Inclusion in PubMed, CAS, Scopus and Google Scholar

- Research which is freely available for redistribution 